Institute of $\mathbf{F}_{\text {ood and }} \mathbf{A}_{\text {gricultural }} \mathbf{S}_{\text {ciences }}$

\title{
Drip Irrigation: The BMP Era - An Integrated Approach to Water and Fertilizer Management for Vegetables Grown with Plasticulture ${ }^{1}$
}

Eric Simonne, David Studstill, Bob Hochmuth, Teresa Olczyk, Michael Dukes, Rafael Munoz-Carpena and Yuncong $\mathrm{Li}^{2}$

In Florida, plasticulture is currently used on approximately 60,000 acres of vegetable (mainly tomato, bell pepper, eggplant, strawberry and watermelon). The Florida drip irrigation school is a one-day educational program offered by the Institute of Food and Agricultural Sciences at the University of Florida focusing on drip irrigation. Through talks, hands-on demonstrations and discussions, the goal of this program is to teach and help vegetable growers better manage fertilizer, water and fumigant applications through drip systems and to prepare them for the BMP era. This program involves county and state-wide Extension faculty and researchers, and members of the irrigation and fertilization industries.

Additional Florida Drip Irrigation Schools are being scheduled regularly thoughout Florida. These programs are offered at no charge, but require pre-registration. Contact your local Extension office to find out when the next drip irrigation school will be offered in your area or check announcements in the
Vegetarian newsletter at

http://www.hos.ufl.edu/vegetarian/vegetarian.htm

This article presents a summary of the information discussed on fertilizer management, irrigation scheduling, and drip system maintenance and troubleshooting. A list of additional references is also included.

\section{Total Maximum Daily Loads (TMDL) and Best Management Practices (BMP): The Basics}

As the development of TMDLs and BMPs for vegetables grown in Florida takes place, growers are eager to find out how this process will affect their operations. TMDLs and BMPs have their origin in Federal and State legislations (Table 1). A TMDL is the maximum amount of a pollutant a water body can receive and still meet its water quality standards. BMPs are specific cultural practices that aim at reducing the load of a specific compound, while maintaining economical yields (Table 2). Growers

1. This document is HS917, one of a series of the Horticultural Sciences Department, Florida Cooperative Extension Service, Institute of Food and Agricultural Sciences, University of Florida. Publication date: March 2003. Please visit the EDIS Web site at http://edis.ifas.ufl.edu.

2. Eric Simonne, assistant professor, David Studstill, biologist, Horticultural Sciences Department; Bob Hochmuth, extension agent IV, NFREC-Live Oak; Teresa Olczyk, extension agent II, Miami-Dade County; Michael Dukes, assistant professor, Agricultural and Biological Engineering Department; Rafael Munoz-Carpena, assistant professor, Agricultural and Biological Engineering Department, Yuncong Li, assistant professor, Soil and Water Science Department, TREC-Homestead, Cooperative Extension Service, Institute of Food and Agricultural Sciences, University of Florida, Gainesville, 32611.

The Institute of Food and Agricultural Sciences is an equal opportunity/affirmative action employer authorized to provide research, educational information and other services only to individuals and institutions that function without regard to race, color, sex, age, handicap, or national origin. For information on obtaining other extension publications, contact your county Cooperative Extension Service office. Florida Cooperative Extension Service/Institute of Food and Agricultural Sciences/University of Florida/Christine Taylor Waddill, Dean. 
will benefit three ways from having a documented BMP plan. They will be offered (1) a waiver of liability from reimbursement of costs or damages associated with the evaluation, assessment, or remediation of nitrate contamination of ground water (F.S. 376.307); (2) a presumption of compliance with state water quality standards [F.S. 403.067 (7)(d)]; and, (3) an oportunity to receive cost-share reimbursement for implementation of selected BMPs [F.S. 570.085(1)].

The BMPs applicable to vegetable production will be included in the Agronomic and Vegetable Crop Water Quality and Water Quantity BMP Manual for Florida for row crops and vegetables, which is under development. BMPs are 1-to-3 page long chapters that include a working definition of the topic, list specific things to do (BMPs) as well as things to avoid (pitfalls), and present existing applicable technical criteria together with additional references. As the new legislative mandate for Florida agriculture, the BMPs largely embrace IFAS fertilization and irrigation recommendations.

\section{Principles of Fertilization Management in the BMP Era}

Fertilization principle 1. With plasticulture, think in terms of rows $Y$ and not in terms of field surface for irrigation and fertilization. For bare ground production of vegetables, fertilizer and irrigation rates are typically expressed in lbs/acre and gallons/acre, respectively. However, when vegetables are grown with plasticulture, the number of linear feet of beds in an acre becomes more important than the actual surface of the field. Growers should think in terms of lbs/100 linear bed feet (lbf) for fertilization injections and gallons/100 lbf for irrigation, and take into account the bed spacing. Typical bed spacings are used in the IFAS fertilization recommendations for plasticulture (Table $3)$.

\section{Fertilization principle 2. Plants need all the} essential nutrients. Sixteen essential mineral elements are recognized as the essential elements. Carbon $(\mathrm{C})$, hydrogen $(\mathrm{H})$, and oxygen $(\mathrm{O})$ are supplied by air and water. Nitrogen $(\mathrm{N})$, phosphorus $(\mathrm{P})$, potassium $(\mathrm{K})$, calcium $(\mathrm{Ca})$, magnesium $(\mathrm{Mg})$, and sulfur (S) are the macronutrients. Boron (B), chlorine $(\mathrm{Cl})$, copper $(\mathrm{Cu})$, iron $(\mathrm{Fe})$, manganese $(\mathrm{Mn})$, molybdenum (Mo), and zinc ( $\mathrm{Zn})$ are the micronutrients. All these elements are essential because (1) vegetable crops cannot complete their life cycle without all of them, (2) typical deficiency symptoms appear when one is not available, and symptoms disappear upon the application of the deficient element, and (3) each element has a specific metabolic role. The overall success of a fertilizer program is determined by the essential element which is provided in smallest quantity (limiting factor). Adequate fertilization together with soil nutrient reserves should provide all these elements in adequate quantities, thereby ensuring that mineral nutrition is not limiting vegetable growth and yield.

Fertilization principle 3. Soil test and follow the recommendation. The only scientific method to apply fertilizer to vegetables is to use a calibrated soil test. A soil sample has to be recent, representative, and large enough to ensure valid results. The soil test recommendation has to be understood, and properly implemented. Typically, $20 \%$ to $50 \%$ of $\mathrm{N}$ and $\mathrm{K}_{2} \mathrm{O}$, and $100 \%$ of $\mathrm{P}_{2} \mathrm{O}_{5}$ and micronutrients are applied preplant. The remaining $50 \%$ to $80 \%$ of $\mathrm{N}$ and $\mathrm{K}_{2} \mathrm{O}$ are injected through the drip system. A fertilizer program may be simply designed from IFAS recommendation using a spreadsheet format (Fig. 1). Correctly implementing soil test results is essential in increasing nutrient management to a level acceptable in the BMP era (Table 4).

Some growers do not believe that economical vegetable yields can be produced with IFAS fertilizer recommendations. Fertilizer recommendations are based on multiple trials and correspond to the fertilizer rates above which no yield response is likely to occur. IFAS fertilizer rate may not be optimal if excessive irrigation is applied. In this case, the solution is to adjust irrigation management, rather than increasing fertilizer rates. Fertilizer applications in excess of the recommended rate should not be made on a routine basis, but only when exceptional circumstances (leaching rain) occur or based on the results of petiole sap test and/or foliar nutrient analyses. IFAS definition of a leaching rain is 3 in. of rain in 3 days or 4 in. of rain in 7 days. 


\begin{tabular}{|c|c|c|c|c|}
\hline & \multicolumn{4}{|c|}{ Fertilizer rate (Ilbs/acre) } \\
\hline & Nitrogen $(\mathrm{N})$ & Phosphorus $\left(\mathrm{P}_{2} \mathrm{O}_{5}\right)$ & & Potassium $\left(\mathrm{K}_{2} \mathrm{O}\right)$ \\
\hline $\begin{array}{l}\text { Total IFAS recommend ation [1] } \\
\text { (based on soil test results) }\end{array}$ & 150 & 0 & & 150 \\
\hline $\begin{array}{l}\text { Preplant tertiluzer (15\% or total N) } \\
\text { (example: } 13-4-13 @ 1731 \mathrm{bs} / \mathrm{acre})\end{array}$ & 22 & 7 & & 22 \\
\hline $\begin{array}{l}\text { Injected fertilizer (85\% of total N) } \\
\text { (ex anple: ifquid } 8-0-8 @ 0.8 \mathrm{~b} \mathrm{~N} / \mathrm{gal} \text { ) }\end{array}$ & 128 & 0 & & 128 \\
\hline \multirow[t]{2}{*}{ week [2] } & \multicolumn{3}{|c|}{ Weeky recommended rate [1] } & \multirow{2}{*}{$\begin{array}{l}\text { 8-0-8 injected } \\
\text { weekly } \\
\text { (gallacre) }\end{array}$} \\
\hline & Nitrogen (N) & Phosphorus $\left(\mathrm{P}_{2} \mathrm{O}_{5}\right)$ & Potass Ium $\left(\mathrm{K}_{2} \mathrm{O}\right)$ & \\
\hline 1 & $7[3]$ & 0 & 7 & $0[4]$ \\
\hline 2 & $7[3]$ & 0 & 7 & $0[4]$ \\
\hline 3 & 10.5 & 0 & 10.5 & 13 \\
\hline 4 & 10.5 & 0 & 10.5 & 13 \\
\hline 5 & 17.5 & 0 & 17.5 & 22 \\
\hline 6 & 17.5 & 0 & 17.5 & 22 \\
\hline 7 & 17.5 & 0 & 17.5 & 22 \\
\hline 8 & 17.5 & 0 & 17.5 & 22 \\
\hline 9 & 10.5 & 0 & 10.5 & 13 \\
\hline 10 & 10.5 & 0 & 10.5 & 13 \\
\hline 11 & 10.5 & 0 & 10.5 & 13 \\
\hline 12 & 7 & 0 & 7 & 9 \\
\hline 13 & $7(1)$ & 0 & $7(1)$ & $0[5]$ \\
\hline \multicolumn{5}{|c|}{ 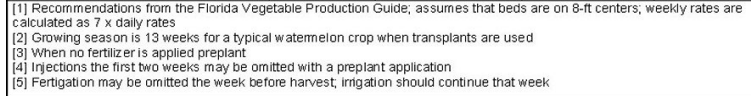 } \\
\hline
\end{tabular}

Figure 1. Sample spreadsheet for designing a fertigation program for a 1-acre watermelon field planted on 8 -ft centers. Beginning with soil-test results (top section), this worksheet that uses IFAS recommendations provides a weekly schedule for fertigation with liquid 8-0-8 (right column).

\section{Fertilization principle 4. Monitor crop} nutritional status and discover how healthy the vegetable plants are. The nutritional status of vegetables may be monitored with sap test or foliar analysis early in the season (from transplanting to fruit set). A representative sample for petiole and leaf analysis should be made with at least 20 leaves selected randomly throughout the field from most recently, fully mature leaves. For sap analysis, blades should be carefully separated from the petiole and discarded. Fig. 2 shows how to collect sap and perform a reading. For leaf analysis, the sampled part should be the blade and its petiole attached.

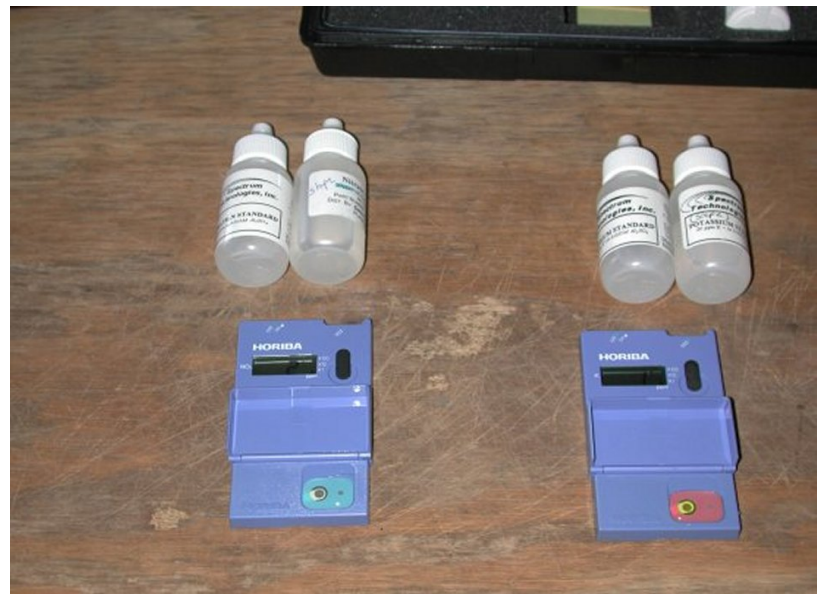

Figure 2.a

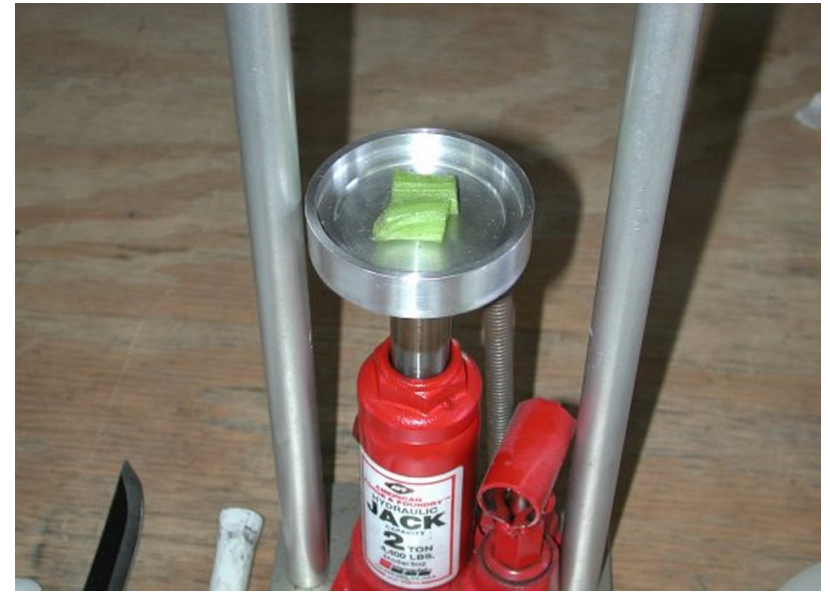

Figure 2.b

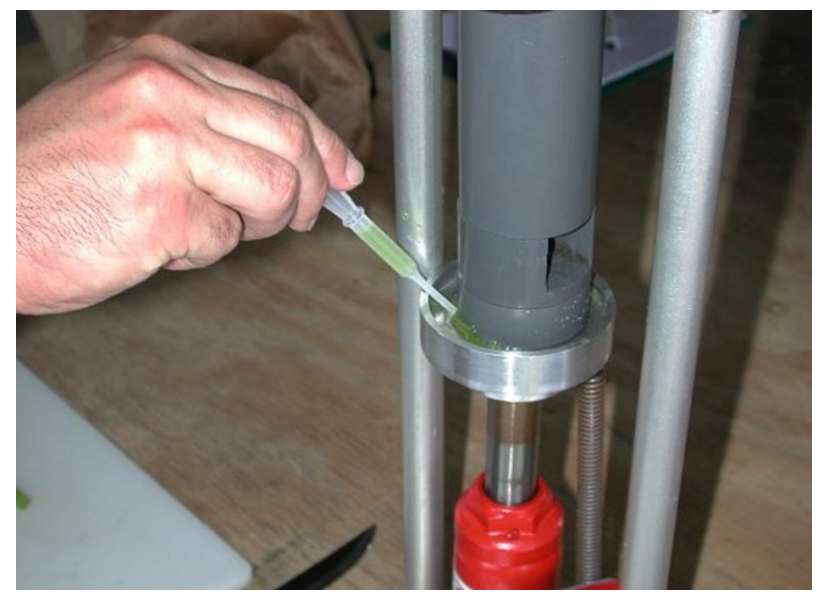

Figure 2.c

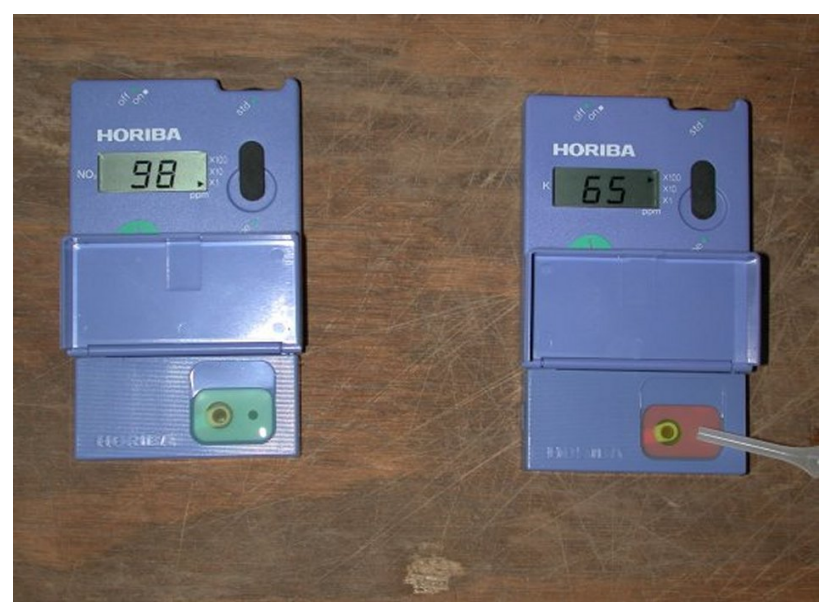

Figure 2.d

Figure 2. Sap testing for vegetables involves separating the petiole from the leaf blade, (2.1) calibrating the nitrate (NO3-N) and potassium (K) ion specific electrodes (Cardi meter shown here) with standard solutions, (2.2) extracting the sap, (2.3) collecting the sap from the press, and (2.4) placing a droplet of sap on the electrode. A hydraulic press may be needed only when few petioles are available or when petioles contain little sap as may occur with strawberry. In most cases, a garlic press will be an adequate tool to extract the sap. Readings should be compared to published sufficiency ranges. 


\section{Principles of Irrigation Scheduling in the BMP Era}

Irrigation scheduling is knowing when to start irrigation and how much to apply, in a way that satisfies crop water needs, conserves water, and does not leach mobile nutrients. Irrigation scheduling requires (1) a target water volume, (2) guidelines on how and when to split irrigation, (3) a method to account for rainfall, and (4) a practical method to monitor soil moisture.

Irrigation principle 1. Irrigation amount must reflect crop water use, no more, no less. Irrigation amounts may be estimated using historical weather data, climatic measurement in real-time, class A pan evaporation, atmometers, and empirical amounts (Table 5, Fig. 3). Empirical values have the advantage of being simple. However, they often result in excessive irrigation early in the season, and insufficient ones later in the season. This method alone (without monitoring of soil moisture) is unlikely to be part of the BMPs.

\section{Drip System Maintenance and Troubleshooting}

Application uniformity of $85 \%$ to $95 \%$ is expected from a new, well-designed drip irrigation system (Fig. 7). As the irrigation system is used for water and fertilizer applications throughout the growing season, the application uniformity may remain the same if the system is well managed, but will most likely decline with time. A comprehensive maintenance plan will reduce the adverse effects of the agents that reduce application uniformity: small solids in suspension, organic matter, micro-organisms, and chemical residues on application uniformity (Fig. 8). Without a maintenance plan, the risk of complete emitter clogging and crop loss becomes real.

\section{References and Additional Readings}

\section{Related Web Sites}

North Florida Research and Education Center Suwannee Valley: http://nfrec-sv.ifas.ufl.edu/

Horticultural Sciences Department:

http://www.hos.ufl.edu

Florida Department of Environmental Protection: http://www.dep.state.fl.us/water

Suwannee River Water Management District: http://www.srwmd.state.fl.us/

Small Scale Irrigation for Arid Zones (FAO): http://www.fao.org/docrep/W3094E/ w3094e00.htm\#TopOfPage

Crop Evapotranspiration - Guidelines for Computing Crop Water Requirements - FAO Irrigation and Drainage Paper 56: http://www.fao.org/docrep/X0490E/X0490E00.htm

University of Florida Extension Soil Testing Laboratory: http://soilslab.ifas.ufl.edu/\#ESTL

NRCS Nutrient Management homepage: http://www.nhq.nrcs.usda.gov/BCS/nutri/ manage.html

\section{General Irrigation}

Soil Plant Water Relationships, D.Z. Haman and F.T. Izuno, Circ. 1085, Fla. Coop. Ext. Ser., IFAS, Univ. of Fla. http://edis.ifas.ufl.edu/AE021

Basic Irrigation Terminology, F.T. Izuno and D.Z. Haman, Fact Sheet AE-66, Fla. Coop. Ext. Ser., IFAS, Univ. of Fla. http://edis.ifas.ufl.edu/AE115

Principles and Practices of Irrigation Management for Vegetables, E.H. Simonne, M.D. Dukes, D.Z. Haman, pp.31-37, In: D.N. Maynard and S.M. Olson (eds.) Vegetable Production Guide for Florida, Univ. of Fla, Gainesville, FL. 


\section{Drip System Maintenance}

Treating Irrigation Systems with Chlorine, G.A. Clark and A.G. Smajstrla, Circ. 1039, Fla. Coop. Ext. Ser., IFAS, Univ. of Fla.

http://edis.ifas.ufl.edu/AE080

Injection of Chemicals Into Irrigation Systems: Rates, Volumes, and Injection Periods, G.A. Clark, D.Z. Haman and F.S. Zazueta, Bul. 250, Fla. Coop. Ext. Ser., IFAS, Univ. of Fla. http://edis.ifas.ufl.edu/AE116

Causes and Prevention of Emitter Plugging in Microirrigation Systems, D.J. Pitts, D.Z. Haman and A.G. Smajstrla, Bul. 258, Fla. Coop. Ext. Ser., IFAS, Univ. of Fla. http://edis.ifas.ufl.edu/AE032

\section{Drip System Components}

Micro-irrigation on Mulched Bed Systems: Components, System Capacities, and Management, G.A. Clark, C.D. Stanley, and A.G. Smajstrla, Bul. 245, Fla. Coop. Ext. Ser., IFAS, Univ. of Fla. http://edis.ifas.ufl.edu/AE042

Media Filters for Trickle Irrigation in Florida, D.Z. Haman, A.G. Smajstrla, and F.S. Zazueta, Fact Sheet AE-57, Fla. Coop. Ext. Ser., IFAS, Univ. of Fla. http://edis.ifas.ufl.edu/WI008

Screen Filters in Trickle Irrigation Systems, D.Z. Haman, A.G. Smajstrla and F.S. Zazueta, Fact Sheet AE-69, Fla. Coop. Ext. Ser., IFAS, Univ. of Fla. http://edis.ifas.ufl.edu/WI009

Principles of Micro Irrigation, D.Z. Haman and F.T. Izuno, Fact Sheet AE-24, Fla. Coop. Ext. Ser., IFAS, Univ. of Fla. http://edis.ifas.ufl.edu/WI007

Chemical Injection Methods for Irrigation, D.Z. Haman, A.G. Smajstrla and F.S. Zazueta, Circ. 864, Fla. Coop. Ext. Ser., IFAS, Univ. of Fla. http://edis.ifas.ufl.edu/WI004

Measuring Pump Capacity for Irrigation System Design, A.G. Smajstrla, D.Z. Haman and F.S. Zazueta, Circ. 1133, Fla. Coop. Ext. Ser., IFAS, Univ. of Fla. http://edis.ifas.ufl.edu/AE067
Florida Backflow Prevention Requirements for Agricultural Irrigation Systems, A.G. Smajstrla, D.S. Harrison, W.J. Becker, F.S. Zazueta, and D.Z. Haman, Bul. 217, Fla. Coop. Ext. Ser., IFAS, Univ. of Fla.

\section{Drip System Design}

Water Hammer in Irrigation Systems, G.A. Clark, A.G. Smajstrla, and D.Z. Haman, Circ. 848, Fla. Coop. Ext. Ser., IFAS, Univ. of Fla. http://edis.ifas.ufl.edu/AE066

Design Tips for Drip Irrigation of Vegetables, D.Z. Haman and A.G. Smajstrla, Fact Sheet AE-260, Fla. Coop. Ext. Ser., IFAS, Univ. of Fla. http://edis.ifas.ufl.edu/AE093

Efficiencies of Florida Agricultural Irrigation Systems, A.G. Smajstrla, B.J. Boman, G.A. Clark, D.Z. Haman, D.S. Harrison, F.T. Izuno, D.J. Pitts and F.S. Zazueta, Bul. 247, Fla. Coop. Ext. Ser., IFAS, Univ. of Fla. http://edis.ifas.ufl.edu/AE110

Field Evaluation of Microirrigation Water Application Uniformity, A.G. Smajstrla, B.J. Boman, D.Z. Haman, D.J. Pitts, and F.S. Zazueta, Bul. 265, Fla. Coop. Ext. Ser., IFAS, Univ. of Fla. http://edis.ifas.ufl.edu/AE094

Flushing Procedures for Microirrigation Systems, A.G. Smajstrla and B.J. Boman, Bul. 333, Fla. Coop. Ext. Ser., IFAS, Univ. of Fla. http://edis.ifas.ufl.edu/WI013

\section{Irrigation Scheduling}

Microirrigation in Mulched Bed Production Systems: Irrigation Depths, G.A. Clark and D.Z. Haman, Fact Sheet AE-49, Fla. Coop. Ext. Ser., IFAS, Univ. of Fla. http://edis.ifas.ufl.edu/AE049

Using Reference Evapotranspiration Data, G.A. Clark, Fact Sheet 251, Fla. Coop. Ext. Ser., IFAS, Univ. of Fla. http://edis.ifas.ufl.edu/AE073

Scheduling Tips for Drip Irrigation of Vegetables, D.Z. Haman and A.G. Smajstrla, Fact Sheet AE-249, Fla. Coop. Ext. Ser., IFAS, Univ. of Fla. http://edis.ifas.ufl.edu/AE092 
Alternatives of Low Cost Soil Moisture Monitoring Devices for Vegetable in South Miami-Dade County. R. Muñoz-Carpena, Y. Li and T. Fact Sheet AE-230, Fla. Coop. Ext. Ser., IFAS, Univ. of Fla. http://edis.ifas.ufl.edu/AE230

Using Tensiometers for Vegetable Irrigation Scheduling in Miami-Dade County, T. Olczyk, Y. Li, and R. Munoz-Carpena, FactSheet ABE 326, Fla. Coop. Ext. Ser., IFAS, Univ. of Fla. http://edis.ifas.ufl.edu/TR015

On-farm Irrigation Scheduling for Vegetables Using the Watermark Soil Moisture Sensor, E. Simonne, A. Andreasen, D. Dinkins, J. Fletcher, R. Hochmuth, J. Simmons, M. Sweat, and A. Tyree, Proceedings of the 2001 Florida Agricultural Conference \& Trade Show, Lakeland FL, October 2-3, 2001, pp. 17-22.

Basic Irrigation Scheduling in Florida, A.G. Smajstrla, B.J. Boman, D.Z. Haman, F.T. Izuno, D.J. Pitts and F.S. Zazueta, Bul. 249, Fla. Coop. Ext. Ser., IFAS, Univ. of Fla. http://edis.ifas.ufl.edu/AE111

Irrigation Scheduling with Evaporation Pans, A. G. Smajstrla, F. S. Zazueta, G. A. Clark, and D. J. Pitts, Bul. 254, Fla. Coop. Ext. Ser., IFAS, Univ. of Fla. http://edis.ifas.ufl.edu/AE118

Trickle Irrigation Scheduling. I: Duration of Water Application, A.G. Smasjtrla, D.S. Harrison, and G.A. Clark, Bul. 204, Fla. Coop. Ext. Ser., IFAS, Univ. of Fla.

Potential Impacts of Improper Irrigation System Design, A.G. Smajstrla, F.S. Zazueta, and D.Z. Haman, Fact Sheet AE-73, Fla. Coop. Ext. Ser., IFAS, Univ. of Fla. http://edis.ifas.ufl.edu/AE027

Tensiometers for Soil Moisture Measurement and Irrigation Scheduling, A.G. Smajstrla and D.S. Harrison, Circ-487, Fla. Coop. Ext. Ser., IFAS, Univ. of Fla. http://edis.ifas.ufl.edu/AE146

Tensiometer Service, Testing and Calibration, A.G. Smajstrla and D.J. Pitts, Bul. 319, Fla. Coop. Ext. Ser., IFAS, Univ. of Fla. http://edis.ifas.ufl.edu/AE086

\section{Nutrient Management}

Commercial Vegetable Fertilization Principles, G.J. Hochmuth and E.A. Hanlon, Circ. 225-E, Fla. Coop. Ext. Ser., IFAS, Univ. of Fla. http://edis.ifas.ufl.edu/CV009

IFAS Standardized Fertilization Recommendations for Vegetable Crops, G.J. Hochmuth and E.A. Hanlon, Circ. 1152, Fla. Coop. Ext. Ser., IFAS, Univ. of Fla. http://edis.ifas.ufl.edu/CV002

Plant Petiole Sap-testing for Vegetable Crops, G. Hochmuth, Circ. 1144, Fla. Coop. Ext. Ser., IFAS, Univ. of Fla. http://edis.ifas.ufl.edu/CV004

Fertilizer Application and Management for Micro (Drip)-irrigated Vegetables, G.J. Hochmuth and A.G. Smajstrla, Cir. 1181, Fla. Coop. Ext. Ser., IFAS, Univ. of Fla. http://edis.ifas.ufl.edu/CV141

Soil and Fertilizer Management for Vegetable Production in Florida, pp.3-14, Simonne, E.H. and G.J. Hochmuth, In: D.N. Maynard and S.M. Olson (eds.) Vegetable Production Guide for Florida, Univ. of Florida, Gainsville, FL. 
Table 1. A brief legislative history of the Best Management Practices (BMP).

\begin{tabular}{|c|c|c|c|}
\hline Year & Origin & Legislation & Public law \# \\
\hline 1948 & US Congress & Water Pollution Control Act (WPCA) & $89-234$ \\
\hline 1965 & US Congress & $\begin{array}{l}\text { Amendment to the WPCA created fed. approved water quality } \\
\text { standards for interstate waters. Name changed to Water Quality Act }\end{array}$ & $89-234$ \\
\hline 1972 & US Congress & $\begin{array}{l}\text { Amendment 303(d) to WQA introduced Total Maximum Daily Loads } \\
\text { (TMDL). Name changed to Federal Water Pollution Control Act } \\
\text { (FWPCA) }\end{array}$ & $92-500$ \\
\hline 1977 & US Congress & $\begin{array}{l}\text { FWPCA amended to introduce BMP development and renamed } \\
\text { Clean Water Act }\end{array}$ & $95-217$ \\
\hline 1987 & US Congress & $\begin{array}{l}\text { Amendments } 304(1) \text { and } 319 \text { introduced the development of } \\
\text { numerical rather than qualitative water quality criteria. New name: } \\
\text { Water Quality Act }\end{array}$ & $100-4$ \\
\hline 1987 & $\begin{array}{l}\text { Florida } \\
\text { Legislature }\end{array}$ & $\begin{array}{l}\text { The Florida Surface Water Improvement and Management (SWIM) } \\
\text { ACT created a program which focuses on preservation of the state's } \\
\text { water bodies that were in good condition, and restoration of some of } \\
\text { its most significant water bodies. }\end{array}$ & $\begin{array}{l}373.451- \\
373.4595\end{array}$ \\
\hline
\end{tabular}

Table 2. Driving forces behind the vegetable BMPs.

\begin{tabular}{||l|l||}
\hline \multicolumn{1}{|c|}{ BMPs are meant to be } & \multicolumn{1}{|c||}{ Comments } \\
\hline Educational & $\begin{array}{l}\text { Through teaching and demonstration, the BMP process aims at } \\
\text { raising the level of nutrient and irrigation management of } \\
\text { growers. }\end{array}$ \\
\hline Economically sound & $\begin{array}{l}\text { BMP implementation is not aimed at reducing production or } \\
\text { crop value. }\end{array}$ \\
\hline Environmentally robust & $\begin{array}{l}\text { BMPs are tools to achieve the TMDLs and therefore reduce } \\
\text { nutrient discharge. }\end{array}$ \\
\hline Based on science & $\begin{array}{l}\text { Only science-based information will separate the facts from the } \\
\text { perceptions. }\end{array}$ \\
\hline \hline
\end{tabular}


Table 3. Typical bed spacing used in vegetables production and corresponding linear bed feet per acre. This spacing is used for fertilizer recommendations. When a different bed spacing is used, fertigation should be adjusted accordingly.

\begin{tabular}{|c|l|c||}
\hline \hline \multicolumn{1}{|c||}{ Bed Spacing } & \multicolumn{1}{|c|}{ Vegetable Crop } & \multicolumn{1}{c|}{ Linear Bed Feet in One Acre } \\
\hline 4 & Strawberry, lettuce & 10,890 \\
\hline 5 & Muskmelon & 8,712 \\
\hline 6 & $\begin{array}{l}\text { Bell pepper, tomato, eggplant, } \\
\text { cucumber, summer squash, } \\
\text { cabbage, broccoli, cauliflower }\end{array}$ & 7,260 \\
\hline 8 & Watermelon & 5,445 \\
\hline Linear bed feet per acre are calculated by dividing 43,560 sq-ft per acre by the bed spacing.
\end{tabular}

Table 4. Levels of fertilizer and water management and corresponding fertilization and irrigation practices for vegetables.

\begin{tabular}{|c|c|c|}
\hline Management Level & Nutrient Management & Irrigation Management \\
\hline 0 - None & Guessing & Guessing \\
\hline 1 - Very low & Soil testing and still guessing & Using the "feel and see" method \\
\hline 2 - Low & $\begin{array}{l}\text { Soil testing and implementing 'a' } \\
\text { recommendation (not sure about how to } \\
\text { correctly implement IFAS recommendations) }\end{array}$ & $\begin{array}{l}\text { Using systematic irrigation for the entire } \\
\text { growing season based on irrigation time (for } \\
\text { example, three hours per day) and not water } \\
\text { volume applied }\end{array}$ \\
\hline 3 - Intermediate & $\begin{array}{l}\text { Soil testing, understanding IFAS } \\
\text { recommendations, and correctly implementing } \\
\text { them }\end{array}$ & $\begin{array}{l}\text { Using a soil moisture measuring tool to start } \\
\text { irrigation }\end{array}$ \\
\hline 4 - Advanced & $\begin{array}{l}\text { Soil testing, understanding IFAS } \\
\text { recommendations, correctly implementing } \\
\text { them, and monitoring crop nutritional status }\end{array}$ & $\begin{array}{l}\text { Using a soil moisture measuring tool to } \\
\text { schedule irrigation and apply amounts based } \\
\text { on a budgeting procedure }\end{array}$ \\
\hline 5 - Recommended & $\begin{array}{l}\text { Soil testing, understanding IFAS } \\
\text { recommendations, correctly implementing } \\
\text { them, monitoring crop nutritional status, and } \\
\text { practice year-round nutrient management } \\
\text { and/or following BMPs }\end{array}$ & $\begin{array}{l}\text { Adjusting irrigation to plant water use, and } \\
\text { using a dynamic water balance based on a } \\
\text { budgeting procedure and plant stage of } \\
\text { growth, together with a soil moisture } \\
\text { measuring tool and/or following BMPs }\end{array}$ \\
\hline
\end{tabular}


Table 5. Comparison of methods available for determining crop water use and their adoption level by the vegetable industry in Florida. Although the most promising method uses real-time potential evapotranspiration data, empirical methods are most commonly used by the industry.

\begin{tabular}{|c|c|c|c|c|}
\hline Method & Principle & Advantages & Limitation & $\begin{array}{l}\text { Level of Adoption } \\
\text { by Industry }\end{array}$ \\
\hline $\begin{array}{l}\text { Historical potential } \\
\text { evapotranspiration }\end{array}$ & $\begin{array}{l}\text { Weather data } \\
\text { from the past } \\
30+\text { years are } \\
\text { averaged to } \\
\text { estimate ETo }\end{array}$ & $\begin{array}{l}\text { IFAS recommended method } \\
\text { Crop water use }(E T c) \text { simply } \\
\text { calculated as ETc=Kc } \times \text { ETo, } \\
\text { where } K c \text { is the crop coefficient }\end{array}$ & $\begin{array}{l}\text { Year to year } \\
\text { variability may be } \\
+/-20 \% \text { of the } \\
\text { historical average } \\
\text { Most Kc values } \\
\text { available are for } \\
\text { bare-ground } \\
\text { production }\end{array}$ & None \\
\hline $\begin{array}{l}\text { Real time potential } \\
\text { evapotranspiration }\end{array}$ & $\begin{array}{l}\text { ETo is } \\
\text { computed daily } \\
\text { using } \\
\text { site-specific, } \\
\text { current weather } \\
\text { data }\end{array}$ & $\begin{array}{l}\text { Data more available as the } \\
\text { FAWN system expands } \\
\text { Increasingly attractive as the } \\
\text { cost of small, on-farm weather } \\
\text { stations keeps decreasing } \\
\text { Crop water use (ETc) simply } \\
\text { calculated as ETc = Kc } \times \text { ETo, } \\
\text { where Kc is the crop coefficient. } \\
\text { Variable Kc allows daily } \\
\text { irrigation adjustment depending } \\
\text { on crop age and weather } \\
\text { demand. } \\
\text { Likely to be part of BMPs }\end{array}$ & $\begin{array}{l}\text { Most Kc values } \\
\text { available are for } \\
\text { bare-ground } \\
\text { production }\end{array}$ & $\begin{array}{l}\text { Currently limited, but } \\
\text { with real potential }\end{array}$ \\
\hline $\begin{array}{l}\text { Class A pan } \\
\text { evaporation (Ep) }\end{array}$ & $\begin{array}{l}\text { ETo is related } \\
\text { to water loss } \\
\text { from a free } \\
\text { water surface }\end{array}$ & $\begin{array}{l}\text { Crop water use (ETc) simply } \\
\text { calculated as ETc }=C F \times \text { Ep, } \\
\text { where } C F \text { is the crop factor. } \\
\text { For practical purposes, CF and } \\
\text { Kc can be inter-converted } \\
\text { Principle can be used with pans } \\
\text { other the expensive class A pan } \\
\text { Variable Kc allows daily } \\
\text { irrigation adjustment depending } \\
\text { on crop age and weather demand } \\
\text { Possible alternative BMP method }\end{array}$ & $\begin{array}{l}\text { Most CF values } \\
\text { available are for } \\
\text { bare-ground } \\
\text { production } \\
\text { Old method that } \\
\text { was not adopted } \\
\text { widely }\end{array}$ & $\begin{array}{l}\text { Virtually unused; } \\
\text { should be replaced } \\
\text { by the method } \\
\text { above }\end{array}$ \\
\hline Atmometers & $\begin{array}{l}\text { Water loss from } \\
\text { a ceramic plate } \\
\text { with a canvas } \\
\text { cover mimics } \\
\text { ETo }\end{array}$ & $\begin{array}{l}\text { Simple principle: water loss from } \\
\text { a small surface closely } \\
\text { estimates ETo } \\
\text { Units are rather inexpensive }\end{array}$ & $\begin{array}{l}\text { Calibration data } \\
\text { usually not } \\
\text { available }\end{array}$ & None \\
\hline
\end{tabular}


Table 5. Comparison of methods available for determining crop water use and their adoption level by the vegetable industry in Florida. Although the most promising method uses real-time potential evapotranspiration data, empirical methods are most commonly used by the industry.

\begin{tabular}{|c|c|c|c|c|}
\hline Method & Principle & Advantages & Limitation & $\begin{array}{l}\text { Level of Adoption } \\
\text { by Industry }\end{array}$ \\
\hline $\begin{array}{l}\text { Empirical } \\
\text { methods }\end{array}$ & $\begin{array}{l}\text { Rely on } \\
\text { experience and } \\
\text { individual } \\
\text { knowledge to } \\
\text { estimate } \\
\text { irrigation } \\
\text { needs }\end{array}$ & $\begin{array}{l}\text { Simple to implement } \\
\text { Most farmers' favorite }\end{array}$ & $\begin{array}{l}\text { Based on } \\
\text { experience, rather } \\
\text { than science } \\
\text { Typically results in } \\
\text { over-irrigation } \\
\text { early in the } \\
\text { season, and } \\
\text { sometimes } \\
\text { under-irrigation } \\
\text { during peak } \\
\text { demand periods } \\
\text { Likely to be } \\
\text { insufficient in the } \\
\text { BMP era }\end{array}$ & Industry standard \\
\hline
\end{tabular}

Table 6. Effect of irrigation amount on water movement in three vegetable growing areas of Florida. Increasing irrigation volume increases vertical downward movement at a faster rate than the lateral movement. Emitter-to-emitter coverage (length) was reached after 3 hours with 12-in emitter spacings, while it was reached in only one hour with 4-in emitter spacing.

\begin{tabular}{|c|c|c|c|c|c|c|c|}
\hline $\begin{array}{l}\text { Irrigation volume } \\
\quad(\mathrm{gph} / 100 \mathrm{ft})\end{array}$ & $\begin{array}{l}\text { Irrigation } \\
\text { Time (hr) }\end{array}$ & $\begin{array}{c}\text { Vertical } \\
\text { depth (in) }\end{array}$ & Width (in) & $\begin{array}{l}\text { Length } \\
\text { (in) }\end{array}$ & $\begin{array}{c}\text { Vertical } \\
\text { depth (\%) }\end{array}$ & Width (\%) & Length (\%) \\
\hline \multicolumn{8}{|c|}{ Hillsborough County - 12-in emitter spacing drip tape (27 gal/100ft/hr) } \\
\hline 27 & 1 & 9 & 11 & 10 & 66 & 25 & 83 \\
\hline 54 & 2 & 12 & 15 & 11.5 & 73 & 38 & 92 \\
\hline 81 & 3 & 14 & 16 & 11 & 97 & 43 & 100 \\
\hline 108 & 4 & 13 & 17 & 11 & 97 & 51 & 100 \\
\hline 162 & 6 & 17 & 20 & 12 & 110 & 54 & 100 \\
\hline 216 & 8 & 17 & 22 & 12 & 110 & 64 & 100 \\
\hline \multicolumn{8}{|c|}{ Hendry County - 18-in emitter spacing drip tape (24 gal/100ft/hr) } \\
\hline 12 & 0.5 & 7 & 6 & 6 & 50 & 17 & 33 \\
\hline 24 & 1 & 9 & 7 & 7 & 61 & 19 & 39 \\
\hline 36 & 1.5 & 10 & 9 & 8 & 68 & 23 & 43 \\
\hline 48 & 2 & 10 & 9 & 8 & 68 & 24 & 46 \\
\hline 72 & 3 & 12 & 10 & 11 & 80 & 26 & 59 \\
\hline 96 & 4 & 17 & 9 & 14 & 115 & 25 & 80 \\
\hline 144 & 6 & 15 & 10 & 10 & 102 & 28 & 80 \\
\hline
\end{tabular}


Table 6. Effect of irrigation amount on water movement in three vegetable growing areas of Florida. Increasing irrigation volume increases vertical downward movement at a faster rate than the lateral movement. Emitter-to-emitter coverage (length) was reached after 3 hours with 12-in emitter spacings, while it was reached in only one hour with 4-in emitter spacing.

\begin{tabular}{|c|c|c|c|c|c|c|c|}
\hline $\begin{array}{l}\text { Irrigation volume } \\
\quad(\mathrm{gph} / 100 \mathrm{ft})\end{array}$ & $\begin{array}{c}\text { Irrigation } \\
\text { Time (hr) }\end{array}$ & $\begin{array}{c}\text { Vertical } \\
\text { depth (in) }\end{array}$ & Width (in) & $\begin{array}{l}\text { Length } \\
\text { (in) }\end{array}$ & $\begin{array}{c}\text { Vertical } \\
\text { depth (\%) }\end{array}$ & Width (\%) & Length (\%) \\
\hline 192 & 8 & 13 & 10 & 9 & 100 & 28 & 80 \\
\hline \multicolumn{8}{|c|}{ Gadsden County - 4-in emitter spacing drip tape (33 gal/100ft/hr) } \\
\hline 33 & 1 & 6 & 8 & 4 & 60 & 22 & 100 \\
\hline 66 & 2 & 8 & 12 & 4 & 80 & 33 & 100 \\
\hline 132 & 4 & 7 & 20 & 4 & 70 & 56 & 100 \\
\hline 198 & 6 & 8 & 23 & 4 & 80 & 64 & 100 \\
\hline \multicolumn{8}{|c|}{$\begin{array}{l}\text { Vertical depth }(\mathrm{V})=\text { vertical length from the top of the bed to the bottom of the blue ring; Vmax }=15 \text { in, except in Gadsen co. } \\
\text { where a clay layer was found at the } 10 \text {-in depth). Width = Hortizontal length perpendicular to the bed axis at the widest point } \\
\text { of the wetting bulb; Wmax = bed width }=36 \text { in at all three locations. Length = Horizontal length parallel to the bed axis at the } \\
\text { widest point of the wetting bulb; Lmax = emitter spacing. }\end{array}$} \\
\hline
\end{tabular}

Table 7. Comparison of soil moisture measuring devices available to vegetable growers. While cost of the unit is always an issue, adoption of these techniques has been mainly determined by maintenance, reliability and dedication issues.

\begin{tabular}{|c|c|c|c|c|}
\hline $\begin{array}{l}\text { Point of } \\
\text { comparison }\end{array}$ & Tensiometer & $\begin{array}{c}\text { Granular Matrix } \\
\text { Sensor (GMS) }\end{array}$ & Dielectric probe & $\begin{array}{l}\text { Time Domain } \\
\text { Reflectometry } \\
\text { (TDR) probe }\end{array}$ \\
\hline $\begin{array}{l}\text { Principle of } \\
\text { operation }\end{array}$ & $\begin{array}{l}\text { Direct measurement of } \\
\text { soil suction: changes in } \\
\text { moisture in a porous cup } \\
\text { in equilibrium with the } \\
\text { soil can be expressed as } \\
\text { changes in air pressure } \\
\text { inside the cup }\end{array}$ & $\begin{array}{l}\text { Indirect measurement } \\
\text { of soil suction: in } \\
\text { saturated saline } \\
\text { condition, electrical } \\
\text { conductivity is a } \\
\text { function of soil } \\
\text { moisture tension }\end{array}$ & $\begin{array}{l}\text { Indirect } \\
\text { measurement of } \\
\text { water content: the } \\
\text { soil dielectric } \\
\text { constant depends } \\
\text { on soil moisture and } \\
\text { can be measured as } \\
\text { an electrical signal } \\
\text { (in volts) }\end{array}$ & $\begin{array}{l}\text { Indirect } \\
\text { measurement of } \\
\text { water content: the } \\
\text { soil dielectric } \\
\text { constant depends } \\
\text { on soil moisture and } \\
\text { can be measured } \\
\text { as an the speed of } \\
\text { travel of wave } \\
\text { signal (in seconds) }\end{array}$ \\
\hline Unit reported to user & $\begin{array}{l}\text { Soil water tension (cb or } \\
\mathrm{kPa} \text { ) }\end{array}$ & $\begin{array}{l}\text { Soil water tension (cb } \\
\text { or } \mathrm{kPa} \text { ) }\end{array}$ & $\begin{array}{l}\text { Volumetric water } \\
\text { content (\%) }\end{array}$ & $\begin{array}{l}\text { Volumetric water } \\
\text { content (\%) }\end{array}$ \\
\hline $\begin{array}{l}\text { Cost for a complete } \\
\text { operating unit }\end{array}$ & $\$ 70-110$ & $\begin{array}{l}\$ 400-480 \\
(\$ 40 \text { for } 2 \text { GMS } \\
\text { blocks, } \$ 400 \text { for } \\
\text { reader) }\end{array}$ & $\begin{array}{l}\$ 525 \text { ( } \$ 150 \text { for } \\
\text { sensor, } \$ 375 \text { for } \\
\text { reader) }\end{array}$ & $\begin{array}{l}\$ 585 \text { ( } \$ 260 \text { for } \\
\text { sensor, } \$ 325 \text { for } \\
\text { reader) }\end{array}$ \\
\hline Life span & Several years & $\begin{array}{l}\text { Few years for } \\
\text { sensors, many years } \\
\text { for reader }\end{array}$ & Many years & Many years \\
\hline
\end{tabular}


Table 7. Comparison of soil moisture measuring devices available to vegetable growers. While cost of the unit is always an issue, adoption of these techniques has been mainly determined by maintenance, reliability and dedication issues.

\begin{tabular}{||l|l|l|l|l||}
\hline \multicolumn{1}{|c|}{$\begin{array}{c}\text { Point of } \\
\text { comparison }\end{array}$} & \multicolumn{1}{|c|}{ Tensiometer } & \multicolumn{1}{|c|}{$\begin{array}{c}\text { Granular Matrix } \\
\text { Sensor (GMS) }\end{array}$} & \multicolumn{1}{|c||}{ Dielectric probe } & \multicolumn{1}{|c|}{$\begin{array}{c}\text { Time Domain } \\
\text { Reflectometry } \\
\text { (TDR) probe }\end{array}$} \\
\hline $\begin{array}{l}\text { Fragility and risk of } \\
\text { damage }\end{array}$ & Very high & Low to very low & Low & Very low \\
\hline Set-up & Involved & Minor & Minimal & Minimal \\
\hline Maintenance & High, very important & None & None & None \\
\hline $\begin{array}{l}\text { Time needed for } \\
\text { equilibrium with soil } \\
\text { (first reading) }\end{array}$ & Few hours & Few hours & Instantaneous & Instantaneous \\
\hline $\begin{array}{l}\text { Change in moisture } \\
\text { reading in response } \\
\text { to change in soil } \\
\text { moisture }\end{array}$ & Fast & $\begin{array}{l}\text { Fast for fine textured } \\
\text { or well compacted } \\
\text { soils, but slow for } \\
\text { coarse-textured } \\
\text { soils }\end{array}$ & Immediate & Immediate \\
\hline $\begin{array}{l}\text { Need for } \\
\text { calibration }\end{array}$ & No (only adjustment) & Yes & Yes & No (yes) \\
\hline \hline
\end{tabular}

Table 8. Components of the maintenance-is-best-medicine program for drip irrigation.

\begin{tabular}{|c|c|c|}
\hline Component & Description and Comments & Few Do's and No-no's! \\
\hline Filtration & $\begin{array}{l}\text { Use } 200 \text {-mesh filter or equivalent when ground water } \\
\text { is used } \\
\text { Consider media filters when surface water is used. } \\
\text { Angular sand particles should be used. } \\
\text { Centrifugal sand separators may be used where } \\
\text { inorganic particle levels greater than } 50 \text { ppm are } \\
\text { present }\end{array}$ & $\begin{array}{l}\text { Do not remove or by-pass filters when } \\
\text { they are clogged. } \\
\text { Clean filter regularly }\end{array}$ \\
\hline Chlorination & $\begin{array}{l}\text { Hypochlorus acid }(\mathrm{HOCl}) \text { is the chemical that } \\
\text { controls bacterial growth } \\
\mathrm{HOCl} \text { may react with iron and create a precipitate } \\
{[\mathrm{Fe}(\mathrm{OH}) 3]} \\
\mathrm{More} \mathrm{Cl} \text { is in the active } \mathrm{HOCl} \text { form at lower } \mathrm{pH} \text { : } \\
90 \% \text { at } \mathrm{pH}=6.5 \\
50 \% \text { at } \mathrm{pH}=7.5 \\
20 \% \text { at } \mathrm{pH}=8.0 \\
\text { Inject enough chlorine to detect } 1 \mathrm{ppm} \mathrm{Cl} \text { at the end } \\
\text { of the line } \\
\text { See references on detailed chlorination procedure }\end{array}$ & $\begin{array}{l}\text { Do not place chlorination point after } \\
\text { filter. Instead, place it before, so that } \\
\text { precipitates may be filtered out } \\
\text { Do not skip chlorination } \\
\text { When well done, chlorination will not } \\
\text { damage the crop } \\
\text { Do handle chlorination products with } \\
\text { care }\end{array}$ \\
\hline Acidification & $\begin{array}{l}\text { Sulfuric ( } \mathrm{H} 2 \mathrm{SO} 4) \text {, hydrochloric }(\mathrm{HCl}) \text { and phosphoric } \\
\text { (H3PO4) acid are the acids most commonly used. } \\
\text { Do run a trial-test in a 55-gal drum to determine the } \\
\text { amount of acid needed }\end{array}$ & $\begin{array}{l}\text { Do not ignore the risks of cross } \\
\text { precipitation with calcium }(\mathrm{Ca}) \text { when } \\
\mathrm{H} 2 \mathrm{SO} 4 \text { or } \mathrm{H} 3 \mathrm{PO} 4 \text { are used } \\
\text { Do handle acids with care }\end{array}$ \\
\hline
\end{tabular}


Table 8. Components of the maintenance-is-best-medicine program for drip irrigation.

\begin{tabular}{||l|l|l||}
\hline \hline Component & \multicolumn{1}{|c||}{ Description and Comments } & \multicolumn{1}{|c||}{ Few Do's and No-no's! } \\
\hline Flushing & $\begin{array}{l}\text { Water velocity and pressure may be increased to 1 } \\
\text { foot/sec at the end of laterals and pressure may be } \\
\text { increased from 8-10 psi to 12 to 15 psi for flushing } \\
\text { Self-flushing valves allow for flushing at every } \\
\text { irrigation, although usually these valves do not } \\
\text { provide flushing long enough and not at the 1 ft/sec } \\
\text { rate } \\
\text { Consider flushing every 2 to 3 weeks }\end{array}$ & $\begin{array}{l}\text { After system is installed, allow for } \\
\text { thorough flushing as soil materials are } \\
\text { likely to be introduced in the system; } \\
\text { then tie the ends } \\
\text { Do not use self-flushing valves in } \\
\text { situations where the system pressure is } \\
\text { too low; they may never close }\end{array}$ \\
\hline Observation & $\begin{array}{l}\text { Regularly look for leaks and system malfunctions } \\
\text { Measure water volume delivered, water travel time, } \\
\text { and pressure changes regularly } \\
\text { Observe crop growth pattern }\end{array}$ & $\begin{array}{l}\text { Do not assume that everything is } \\
\text { working properly! } \\
\text { Be on the lookout } \\
\text { Keep record of benchmark operating } \\
\text { values }\end{array}$ \\
\hline \hline
\end{tabular}

Table 9. Observation component of the prevention-is-best-medicine maintenance program: possible drip irrigation system checks and frequency during the growing season.

\begin{tabular}{||l|l|l|l|l||}
\hline \hline What to check? & How often? & Compared to what? & What to look for? & \multicolumn{1}{|c||}{ Possible Causes } \\
\hline $\begin{array}{l}\text { Pump flow rate } \\
\text { and pressure, for } \\
\text { each irrigation } \\
\text { zone }\end{array}$ & Weekly & $\begin{array}{l}\text { Design, benchmark } \\
\text { flow rate and pressure, } \\
\text { or water travel time } \\
\text { (using dye) }\end{array}$ & $\begin{array}{l}\text { High flow and/or low } \\
\text { pressure } \\
\text { Low flow and/or high } \\
\text { pressure } \\
\text { No flow, no pressure }\end{array}$ & $\begin{array}{l}\text { Leaks in pipelines or laterals } \\
\text { Flush valves remain open } \\
\text { Open end of laterals } \\
\text { Closed zone valves } \\
\text { Pipeline obstruction } \\
\text { Tape clogging } \\
\text { Pump malfunction } \\
\text { Well problems } \\
\text { Broken well shaft } \\
\text { Drop in water level }\end{array}$ \\
\hline $\begin{array}{l}\text { Pressure } \\
\text { difference across } \\
\text { filter }\end{array}$ & $\begin{array}{l}\text { At each } \\
\text { irrigation }\end{array}$ & $\begin{array}{l}\text { Manufacturer } \\
\text { specifications }\end{array}$ & $\begin{array}{l}\text { Exceeds or is close } \\
\text { to maximum } \\
\text { allowable pressure } \\
\text { difference }\end{array}$ & $\begin{array}{l}\text { Filter becoming clogged } \\
\text { Obstruction in filter } \\
\text { Sudden change in water } \\
\text { quality }\end{array}$ \\
\hline $\begin{array}{l}\text { Operating } \\
\text { pressures at ends } \\
\text { of laterals }\end{array}$ & $\begin{array}{l}\text { Monthly, unless } \\
\text { other checks } \\
\text { indicate possible } \\
\text { clogging }\end{array}$ & $\begin{array}{l}\text { Benchmark } \\
\text { pressures }\end{array}$ & $\begin{array}{l}\text { High end pressure } \\
\text { Low end pressure }\end{array}$ & $\begin{array}{l}\text { Possible clogging } \\
\text { High system pressure } \\
\text { Obstruction in tape } \\
\text { Broken lateral } \\
\text { Leaks in laterals } \\
\text { Low system pressure }\end{array}$ \\
\hline \hline
\end{tabular}


Table 9. Observation component of the prevention-is-best-medicine maintenance program: possible drip irrigation system checks and frequency during the growing season.

\begin{tabular}{|c|c|c|c|c|}
\hline What to check? & How often? & Compared to what? & What to look for? & Possible Causes \\
\hline $\begin{array}{l}\text { Water at lateral } \\
\text { ends and flush } \\
\text { valves }\end{array}$ & Bi-weekly & Water source & $\begin{array}{l}\text { Particles in water } \\
\text { Other debris }\end{array}$ & $\begin{array}{l}\text { Broken pipeline } \\
\text { Missing filter screen } \\
\text { Hole in filter screen } \\
\text { Tear in filter mesh } \\
\text { Particles smaller then } \\
\text { screen } \\
\text { Filter problem } \\
\text { Chemical/fertilizer } \\
\text { precipitation } \\
\text { Algae growth } \\
\text { Bacterial growth }\end{array}$ \\
\hline $\begin{array}{l}\text { Overall pump } \\
\text { station }\end{array}$ & Weekly & $\begin{array}{l}\text { Manufacturer's } \\
\text { specification and } \\
\text { values at startup }\end{array}$ & $\begin{array}{l}\text { Leaks, breaks, } \\
\text { engine reservoir } \\
\text { levels, tank levels }\end{array}$ & Mostly mechanical \\
\hline $\begin{array}{l}\text { Injection pump } \\
\text { settings }\end{array}$ & Weekly & $\begin{array}{l}\text { Calibrating setting at } \\
\text { startup }\end{array}$ & $\begin{array}{l}\text { Reduced injection } \\
\text { rate }\end{array}$ & $\begin{array}{l}\text { Injector clogged with debris } \\
\text { (check filter) } \\
\text { Precipitates in the fertilizer } \\
\text { (check fertilizer } \\
\text { compatibility) } \\
\text { Precipitation between high- } \\
\text { calcium water and } \\
\text { phosphates or sulfates in } \\
\text { fertilizer }\end{array}$ \\
\hline Overall system & Weekly & System at startup & $\begin{array}{l}\text { Discoloration at } \\
\text { outlets or ends of } \\
\text { laterals } \\
\text { Leaks in tape } \\
\text { Wilting crop }\end{array}$ & $\begin{array}{l}\text { Indicates possible build up of } \\
\text { minerals, fertilizer, algae, } \\
\text { and/or bacterial slime } \\
\text { Pest or mechanical damage } \\
\text { Tape off fittings } \\
\text { Tape blow out from high } \\
\text { pressure } \\
\text { Insufficient irrigation and/or } \\
\text { high crop transpiration rate } \\
\text { Tape clogged, obstructed or } \\
\text { broken } \\
\text { Root disease (bacterial } \\
\text { and/or fungal soil born } \\
\text { diseases, nematodes) }\end{array}$ \\
\hline
\end{tabular}

